\title{
ANALISIS KEBUTUHAN KONSELING PRANIKAH TENTANG KESEHATAN REPRODUKSI DI LAYANAN PERNIKAHAN DI KOTA TARAKAN
}

\author{
Susanti ${ }^{1}$ \\ 1 Fakultas Ilmu Kesehatan Universitas Borneo Tarakan \\ *Email: shantie.alfarisi@gmail.com
}

\begin{abstract}
Abstrak
Konseling pranikah tidak hanya membahas masalah psikologis pernikahan, namun juga masalah kesehatan khususnya kesehatan reproduksi pasangan. Konseling pranikah dalam masalah kesehatan reproduksi mendiskusikan mengenai fisiologi reproduksi manusia, perencanaan keluarga serta nilai - nilai emosional penting dalam hal reproduksi. Konseling mengenai masalah kesehatan terutama kesehatan reproduksi dapat mendorong pasangan dalam mendiskusikan secara terbuka unsur seksual yang dalam pernikahan memotivasi secara bersama masalah - masalah tentang ekspektasi pasangan dari hubungan seksual dalam pernikahan.

Tujuan penelitian ini adalah untuk mengetahui gambaran pengetahuan calon pengantin tentang kesehatan reproduksi dan untuk menganalisis kebutuhan konseling pranikah tentang kesehatan reproduksi di Kota Tarakan. Penelitian ini adalah penelitian deskriptif dengan total responden calon pengantin sebanyak 51 orang dan 21 petugas di layanan pernikahan. Lokasi penelitian dilaksanakan di seluruh Kantor Urusan Agama (KUA) sebagai penyelenggara pernikahan bagi masyarakat yang beragama Islam dan layanan pernikahan lainnya bagi masyarakat yang bukan beragama Islam seperti gereja - gereja, pura maupun vihara yang ada di kota Tarakan.

Hasil penelitian menunjukkan pengetahuan calon pengantin tentang kesehatan reproduksi secara keseluruhan berkategori baik sebanyak 35 orang $(68,6 \%)$ dan pengetahuan cukup sebanyak 16 orang (31,4\%). Pelaksanaan konseling pranikah di Kota Tarakan secara umum dalam kategori cukup sebanyak 17 tempat pelaksana $(80,95 \%)$ dan kategori kurang sebanyak 4 tempat pelaksana $(19,05 \%)$ yang dinilai mencakup kebijakan, SDM (Sumber Daya Manusia), sarana/prasarana, pedoman; waktu, lama, metode, media dan materi. Adapun kebutuhan konseling pranikah tentang kesehatan reproduksi di Kota Tarakan 90,48\% sangat membutuhkan untuk dilakukan konseling di fasilitas pelayanan pernikahan.
\end{abstract}

Kata kunci : konseling pranikah, kesehatan reproduksi.

\begin{abstract}
Analysis Of The Counseling Needs About Reproductive Health In Wedding Services In Tarakan City. Premarital counseling not only addresses the psychological problems of marriage, but also health problems, especially reproductive health of partners. Premarital counseling on reproductive health issues discusses human reproductive physiology, family planning and important emotional value in terms of reproduction. Counseling on health issues, especially reproductive health, can encourage couples to openly discuss the sexual elements in marriage to motivate together the problem of the couple's expectations of sexual intercourse in marriage. The purpose of this study was to determine the description of bride knowledge about reproductive health and to analyze the need for premarital counseling on reproductive health in the City of Tarakan. This study was a descriptive study with a total of 51 prospective bride respondents and 21 officers at wedding services. The location of the study was carried out in all the Office of Religious Affairs (KUA) as organizers of marriages for Muslim communities and other wedding services for non-Muslim communities such as churches, temples and temples in the city of Tarakan. The results showed the knowledge of the bride about overall reproductive health as good as 35 people (68.6\%) and enough knowledge as many as 16 people (31.4\%). The implementation of premarital counseling in the city of Tarakan in general was in the category of as many as 17 places of implementation (80.95\%) and less categories as many as 4 places of implementation (19.05\%) which were considered to include policies, human resources, facilities guidelines; time, method, media and material. The need for premarital counseling on reproductive health in Tarakan City is $90.48 \%$, in desperate need of counseling at a wedding service facility.
\end{abstract}

Keywords: premarital counseling, reproductive health. 


\section{Pendahuluan}

Undang - undang Perkawinan No.1 tahun 1974 pasal 1 disebutkan bahwa Perkawinan adalah ikatan lahir dan bathin antara seorang pria dengan seorang wanita sebagai suami istri dengan tujuan membentuk keluarga (rumah tangga) yang bahagia dan kekal berdasarkan Ketuhanan Yang Maha Esa.

Menikah berarti pula terjalinnya suatu komitmen dan tanggungjawab di antara sepasang suami istri, dimana mereka wajib mematuhi apa - apa yang menjadi komitmen bersama tersebut secara utuh dan bertanggung jawab. Pernikahan memiliki konsekuensi - konsekuensi yang harus dihadapi secara bersama - sama kemudian hari, sehingga perlu adanya pertimbangan - pertimbangan yang mendalam sebelum pasangan memutuskan untuk menikah.

Persiapan untuk menikah harus dilakukan secara mental dan fisik. Persiapan secara mental dapat dilakukan dengan cara mempersiapkan secara psikologis dan memperhatikan kematangan serta kedewasaan dalam berpikir, sedangkan persiapan fisik adalah persiapan yang berhubungan seputar pengetahuan dan persiapan bagi calon pengantin.

Konseling pranikah merupakan salah satu persiapan yang dapat dilakukan di awal sebelum memasuki pernikahan serta memiliki tujuan dalam mencegah perceraian. Konseling pranikah adalah layanan pemberian bantuan yang dapat diberikan kepada individu sebelum melangsungkan pernikahan. Pelayanan konseling pranikah telah banyak dikembangkan dan dilakukan oleh para ahli atau biro pelayanan konseling. Seorang licenced psychologist, Charles William pada tahun 2000 telah mengembangkan dan melaksanakan konseling pranikah yang bertujuan untuk mengurangi kekecewaan yang ada dalam pernikahan.

Konseling pranikah tidak hanya membahas masalah psikologis pernikahan, namun juga masalah kesehatan dan seks pasangan. Konseling pranikah dalam masalah kesehatan dan seks mendiskusikan mengenai fisiologi reproduksi manusia, perencanaan keluarga serta nilai - nilai emosional penting dalam berhubungan seksual. Konseling mengenai masalah kesehatan terutama kesehatan reproduksi dapat mendorong pasangan dalam mendiskusikan secara terbuka unsur seksual yang dalam pernikahan memotivasi secara bersama masalah masalah tentang ekspektasi pasangan dari hubungan seksual dalam pernikahan.

Aspek medis seringkali diabaikan dalam perencanaan pernikahan. Padahal 
pemeriksaan kesehatan pranikah diperlukan untuk menjaga keharmonisan rumah tangga. Pemeriksaan medis juga penting untuk mendeteksi penyakit dan kelainan yang bisa menular pada pasangan maupun mempengaruhi kesehatan calon ibu dan bakal janin yang dikandungnya. Konseling pranikah dapat memberikan informasi mengenai kesehatan reproduksi. Masalah kesehatan reproduksi di Indonesia kurang mendapat perhatian yang cukup. Hal tersebut disebabkan oleh tingkat pengetahuan yang masih rendah tentang kesehatan reproduksi seperti pencegahan kehamilan yang tidak diinginkan, Infeksi Menular Seksual dan HIV/AIDS. Pemahaman yang baik tentang kesehatan reproduksi dapat menjadi bekal alam menjalankan tugas perkembangan selanjutnya pernikahan.

Kepala Badan Kependudukan dan Keluarga Berencana Nasiaonal (BKKBN) mengatakan bahwa saat ini pengetahuan seks dan reproduksi di kalangan anak muda masih sangat minim. Pengetahuan tentang kesehatan reproduksi agar anak muda Indonesia dapat menjaga usia perkawinan artinya mereka akan berkeluarga setelah benar - benar siap baik secara fisik, biologis, medis, psikologis, social maupun ekonomi. $80 \%$ pakar sepakat bahwa pasangan yang melakukan konseling pra nikah kecil kemungkinan untuk bercerai.

Saat ini para calon pengantin sangat jarang bahkan tidak ada yang memeriksakan kesehatan mereka sebagai calon pengantin. Dari segi kesehatan, pengetahuan dan pemeriksaan kesehatan calon pengantin sangatlah penting. Hal ini bisa menyebabkan saat telah menjalani rumah tangga banyak timbul masalah masalah yang berhubungan dengan kesehatan terutama kesehatan reproduksi seperti PMS, kelainan dalam kehamilan dll. Di Indonesia ada sekitar 2,5 juta calon pengantin yang perlu dididik dalam merencanakan keluarga juga perlu memahami persiapan kehamilan dan kelahiran sehingga hak anak untuk tumbuh dan berkembang tercapai.

Berdasarkan studi pendahuluan dengan melakukan wawancara kepada 6 pasangan yang sudah menikah bahwa saat berencana menikah tidak pernah mendapatkan informasi atau konseling tentang kesehatan khususnya kesehatan reproduksi. Disamping itu bimbingan/konseling pra nikah tentang kesehatan reproduksi di Indonesia belum pernah dikembangkan. Maka hal inilah yang menjadikan peneliti tertarik untuk melakukan penelitian mengenai Analisis Kebutuhan Konseling Pranikah tentang Kesehatan Reproduksi di Kota Tarakan. 


\section{Metode}

Penelitian yang dilakukan bersifat deskriptif, dengan subjek penelitian penghulu di KUA, pendeta di gereja, pura maupun vihara dan calon pengantin yang mendaftarkan pernikahannya ditempat penyelenggara pernikahan baik di KUA, gereja, pura dan vihara.

Data yang dikumpulkan dalam penelitian ini adalah dengan metode kuantitatif dan kualitatif. Metode kuantitatif digunakan untuk mengukur pengetahuan calon pasangan yang akan menikah tentang kesehatan reproduksi dan kondisi nyata pelaksanaan konseling pranikah yang sudah dilaksanakan di tiap tiap tempat penyelenggaraan pernikahan.

Teknik pengumpulan data kuantitatif yang digunakan dalam penelitian ini adalah dengan menyebarkan angket yaitu sejumlah daftar pertanyaan dan pernyataan kepada calon pengantin yang akan menikah dan untuk mengetahui pengetahuan mereka tentang kesehatan reproduksi. Sedangkan untuk pengumpulan data kualitatif dihimpun menggunakan metode interview.

\section{Hasil Dan Pembahasan}

\section{Karakteristik Responden}

Total responden penelitian untuk data kuantitatif tempat layanan pernikahan adalah 22 petugas pelayan pernikahan yang mencakup 5 orang penghulu di Kantor Urusan Agama, 14 orang pendeta di gereja, 2 orang pendeta di vihara dan 1 orang pendeta di pura. Peneliti bermaksud mengumpulkan data dari semua petugas penyelenggara pernikahan yang ada di kota Tarakan. Namun ada 1 vihara yang menolak untuk permohonan penelitian. Banyaknya jumlah gereja di kota Tarakan dan tersebar hingga daerah pelosok membuat peneliti kesulitan untuk menjangkau sehingga hanya difokuskan pada induk - induk gereja seperti induk gereja Katholik dan induk gereja Protestan.

\section{Input Pelaksanaan Konseling Pranikah Di Layanan Pernikahan}

\section{Kebijakan}

Pelaksanaan konseling pranikah dilandasi kebijakan yang terpusat yang dipakai sebagai dasar dan bentuk dukungan dalam melakukan suatu kegiatan di tiap - tiap layanan pernikahan. Sebagai pengambil kebijakan tertinggi dalam lingkungan Kementerian Agama Kota Tarakan adalah Kepala Kantor Kemenag Kota Tarakan.

\section{Sumber daya manusia (SDM)}

Petugas yang memberikan konseling adalah petugas yang ditunjuk secara internal oleh pimpinan tertinggi di fasilitas pelayanan pernikahan dalam hal ini Kepala 
Kantor Urusan Agama di fasilitas pelayanan pernikahan bagi umat muslim dan pendeta di gereja, pura maupun vihara. Tidak ada persyaratan khusus dalam penunjukkan petugas pemberi konseling di tempat tersebut. Bahkan ada beberapa tempat yang menunjuk petugasnya berdasarkan kriteria pengalaman kerja, pengalaman pelatihan, sudah menikah dan merupakan orang yang dituakan atau anggota majelis gereja.

\section{Sarana/prasarana}

Ketersediaan sarana/prasarana penunjang di tiap - tiap layanan pernikahan sebanyak 17 (80,9\%) fasilitas pernikahan telah memiliki ruang konseling walaupun tidak terpisah antara calon pengantin pria dan wanita, sebanyak 14 $(66,7 \%)$ memiliki buku pegangan sebagai media dalam melakukan konseling dan ada 9 tempat $(42,86 \%)$ sudah memiliki leaflet atau brosur.

\section{Pedoman konseling pranikah}

Hampir semua $(95,2 \%)$ fasilitas layanan pernikahan tidak memiliki buku pedoman konseling/nasihat pernikahan yang dijadikan sebagai acuan dalam melaksanakan program penasihatan perkawinan/konseling pranikah. Hanya ada $1(4,8 \%)$ fasilitas layanan pernikahan yang telah memiliki buku pedoman yang dibuat internal dari gereja sendiri sebagai induk gereja Katholik di Kota Tarakan.

\section{Pengetahuan calon pengantin tentang} kesehatan reproduksi

Calon pengantin yang datang mendaftarkan diri mereka untuk menikah memiliki pengetahuan tentang kesehatan reproduksi secara keseluruhan berkategori baik sebanyak 35 orang $(68,6 \%)$ dan pengetahuan yang berkategori cukup sebanyak 16 orang (31,4\%). Namun, pengetahuan yang baik tidak didukung dengan pemahaman yang baik tentang kesehatan reproduksi. Pengetahuan responden hanya berkisar pengetahuan kesehatan reproduksi secara umum seperti pengetahuan secara fisik organ kelamin pada pria dan wanita. Sementara pengetahuan mereka tentang konsep kesehatan reproduksi yang benar, personal hygiene (kebersihan alat kelamin), penyakit menular seksual, gender, keluarga berencana, kanker pada alat reproduksi masih sangat rendah.

\section{Proses Pelaksanaan Konseling Pranikah Di Layanan Pernikahan}

Pelaksanaan konseling pra nikah berdasarkan kebijakan

Table. 1 Pelaksanaan Konseling pra nikah

\begin{tabular}{lcccccccc}
\hline \multirow{2}{*}{ Kebijakan } & \multicolumn{9}{c}{ Pelaksanaan } & \multicolumn{2}{c}{ Total } \\
\cline { 2 - 7 } & \multicolumn{2}{c}{ Kurang } & \multicolumn{2}{c}{ Cukup } & \multicolumn{2}{c}{ Baik } & \\
\cline { 2 - 7 } & $\mathrm{F}$ & $\%$ & $\mathrm{~F}$ & $\%$ & $\mathrm{~F}$ & $\%$ & $\mathrm{~F}$ & $\%$ \\
\hline Ada & 4 & 19,05 & 17 & 80,95 & 0 & 0 & 21 & 100 \\
\hline $\begin{array}{l}\text { Tidak ada } \\
\text { kebijakan }\end{array}$ & 0 & 0 & 0 & 0 & 0 & 0 & 0 & 0 \\
\hline Total & 4 & 19,05 & 17 & 80,95 & 0 & 0 & 21 & 100 \\
\hline
\end{tabular}


Semua pelaksanaan konseling pranikah di kota Tarakan dilakukan berdasarkan kebijakan. Pelaksanaan konseling pra nikah di masing-masing tempat pelayanan pernikahan mengacu pada kebijakan tertinggi yang diatur oleh Kantor Kemenag Kota Tarakan, walaupun dalam pelaksanaannya terdapat hal-hal yang dikembangkan oleh masing-masing tempat layanan seperti pedoman konseling pranikah.

Tabel 2. Pelaksanaan konseling pra nikah berdasarkan ketersediaan SDM

Tabel 3. Pelaksanaan Konseling Pra nikah berdasarkan ketersediaan Sarana/prasarana

\begin{tabular}{|c|c|c|c|c|c|c|}
\hline \multirow{3}{*}{$\begin{array}{l}\text { Ketersediaan } \\
\text { Sarana/prasarana }\end{array}$} & \multicolumn{6}{|c|}{ Pelaksanaan } \\
\hline & \multicolumn{2}{|c|}{ Kurang } & \multicolumn{2}{|c|}{ Cukup } & \multicolumn{2}{|c|}{ Baik } \\
\hline & Ada & $\begin{array}{c}\text { Tida } \\
\mathrm{k} \text { ada }\end{array}$ & Ada & $\begin{array}{l}\text { Tida } \\
\mathrm{k} \text { ada }\end{array}$ & Ada & $\begin{array}{r}\text { Tida } \\
\mathrm{k} \text { ada }\end{array}$ \\
\hline Ruang konseling & 3 & 1 & 13 & 3 & 0 & 0 \\
\hline Buku pegangan & 2 & 2 & 11 & 5 & 0 & 0 \\
\hline Leaflet/brosur & 0 & 4 & 9 & 7 & 0 & 0 \\
\hline
\end{tabular}

Sarana/prasarana ruangan konseling secara umum sudah tersedia di beberapa tempat pelayanan pernikahan walaupun ruang untuk calon pengantin laki-laki dan perempuan tidak dipisah. Untuk ketersediaan leaflet/brosur sebagai media

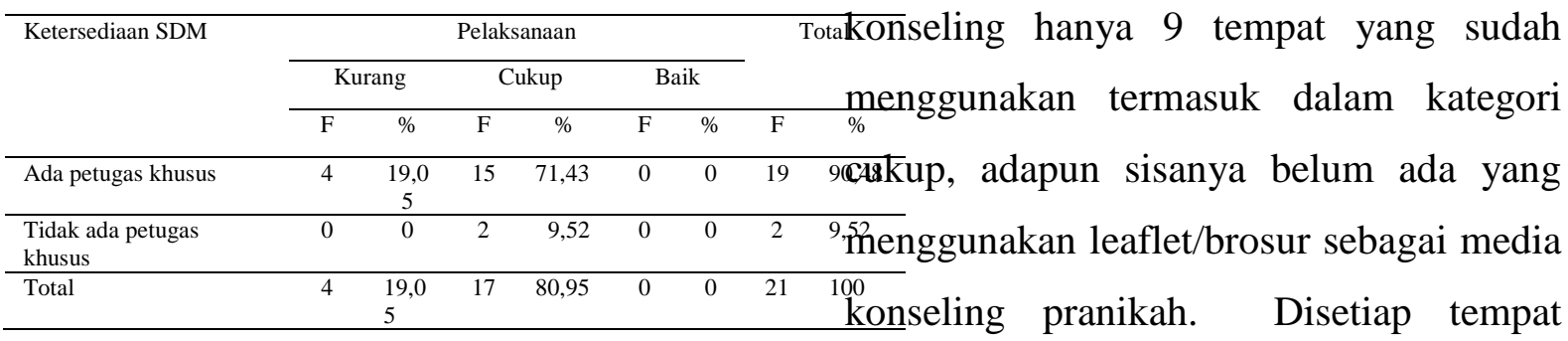

Dari beberapa petugas yang diwawancarai mengatakan seorang petugas seharusnya memiliki pendidikan khusus. Hasil penelitian didapatkan bahwa tidak ada persyaratan khusus dalam penunjukkan petugas pemberi konseling di tempat pelayanan pernikahan. Petugas yang ditunjuk hanya memiliki latarbelakang pernah mendapatkan pelatihan tentang perkawinan dan mengerti tentang dasar-dasar pernikahan. pelayanan pernikahan penyediaan media tergantung dari inovasi masing-masing untuk mengembangkan sarana/prasarana.

Tabel 4. Pelaksanaan konseling pra nikah berdasarkan ketersediaan pedoman

\begin{tabular}{lccccccccc}
\hline \multirow{2}{*}{$\begin{array}{l}\text { Ketersediaan } \\
\text { pedoman }\end{array}$} & \multicolumn{4}{c}{ Pelaksanaan } & \multicolumn{2}{c}{ Total } \\
\cline { 2 - 7 } & \multicolumn{2}{c}{ Kurang } & \multicolumn{2}{c}{ Cukup } & \multicolumn{2}{c}{ Baik } & \\
\cline { 2 - 7 } & $\mathrm{F}$ & $\%$ & $\mathrm{~F}$ & $\%$ & $\mathrm{~F}$ & $\%$ & $\mathrm{~F}$ & $\%$ \\
\hline $\begin{array}{l}\text { Tidak } \\
\text { menggunakan } \\
\text { pedoman }\end{array}$ & 4 & 19,05 & 16 & 76,19 & 0 & 0 & 20 & 95,24 \\
\hline Ada pedoman & 0 & 0 & 1 & 4.76 & 0 & 0 & 1 & 4,76 \\
\hline Total & 4 & 19,05 & 17 & 80,95 & 0 & 0 & 21 & 100 \\
\hline
\end{tabular}

Pada dasarnya pedoman yang digunakan dalam melaksanakan konseling pranikah meliputi acuan materi, alokasi waktu, metode dan media yang digunakan. Pada pelaksanaannya isi pedoman tidak 
terstruktur dengan baik akan tetapi telah dilaksanakan di lapangan. Materi yang diberikan disetiap tempat berbeda-beda diantaranya tentang dasar-dasar pernikahan sesuai Alkitab, UndangUndang perkawinan, pendalaman agama, nilai-nilai pancasila, nasihat pranikah dan perkawinan, dasar hubungan pria dan wanita, tujuan pernikahan, permasalahan dalam keluarga dan cara mengatasinya, persiapan fisik mental, kesehatan seperti keluarga berencana (KB) alami dan seks.

Tabel 5. Pelaksanaan Konseling Pra Nikah Berdasarkan Waktu

\begin{tabular}{|c|c|c|c|c|c|c|c|c|}
\hline \multirow{3}{*}{$\begin{array}{l}\text { Waktu } \\
\text { pemberian } \\
\text { konseling }\end{array}$} & \multicolumn{6}{|c|}{ Pelaksanaan } & \multirow{2}{*}{\multicolumn{2}{|c|}{ Total }} \\
\hline & \multicolumn{2}{|c|}{ Kurang } & \multicolumn{2}{|c|}{ Cukup } & \multicolumn{2}{|c|}{ Baik } & & \\
\hline & $\mathrm{F}$ & $\%$ & $\mathrm{~F}$ & $\%$ & $\mathrm{~F}$ & $\%$ & $\mathrm{~F}$ & $\%$ \\
\hline$<30$ menit & 0 & 0 & 0 & 0 & 0 & 0 & 0 & 0 \\
\hline $\begin{array}{l}30 \text { menit }-1 \\
\text { jam }\end{array}$ & 4 & 19,05 & 17 & 80,95 & 0 & 0 & 21 & 100 \\
\hline$>1$ jam & 0 & 0 & 0 & 0 & 0 & 0 & 0 & 0 \\
\hline Total & 4 & 19,05 & 17 & 80,95 & 0 & 0 & 21 & 100 \\
\hline
\end{tabular}

Di semua tempat pelayanan pernikahan waktu rata-rata pemberian konseling selama 30 sampai 1 jam disetiap pertemuan, walaupun pelaksanaannya beberapa proses konseling bisa lebih dari waktu tersebut diatas, karena kembali lagi dari kebutuhan calon pengantin, dimana dalam proses konseling beberapa calon pengantin dapat sekaligus berkonsultasi dengan petugas konselor. Konseling pranikah disemua tempat sudah wajib dilakukan dengan alasan bahwa calon pengantin harus memahami syarat kesiapan dan bekal dalam membina rumah tangga, mempersiapkan calon pengantin untuk menghadapi masalah setelah menikah dan memahami arti dari pernikahan. Sehingga waktu disetiap kali pertemuan selama 30 menit sampai 1 jam dinilai sangat efektif dilakukan untuk memberi kesempatan kepada calon pengantin mengetahui banyak hal sebelum memasuki jenjeng pernikahan.

Tabel 6. Pelaksanaan Konseling Pra Nikah Berdasarkan Lama Pemberian Konseling

\begin{tabular}{lcccccccc}
\hline \multirow{2}{*}{$\begin{array}{l}\text { Lama } \\
\text { pemberian } \\
\text { konseling }\end{array}$} & \multicolumn{9}{c}{ Pelaksanaan } & \multicolumn{2}{c}{ Total } \\
\cline { 2 - 7 } & Kurang & \multicolumn{2}{c}{ Cukup } & \multicolumn{2}{c}{ Baik } & \\
\cline { 2 - 7 } & $\mathrm{F}$ & $\%$ & $\mathrm{~F}$ & $\%$ & $\mathrm{~F}$ & $\%$ & $\mathrm{~F}$ & $\%$ \\
\hline $1-6$ hari & 4 & 19,05 & 8 & 38,09 & 0 & 0 & 12 & 57,14 \\
\hline $1-2$ & 0 & 0 & 4 & 19,05 & 0 & 0 & 4 & 19,05 \\
$\begin{array}{l}\text { minggu } \\
>2 \text { minggu }\end{array}$ & 0 & 0 & 5 & 23,81 & 0 & 0 & 5 & 23,81 \\
\hline Total & 4 & 19,05 & 17 & 80,95 & 0 & 0 & 21 & 100 \\
\hline
\end{tabular}

Beberapa tempat pelayanan pernikahan khususnya di gereja-gereja kota Tarakan, pada lama pelaksanaan pemberian konseling rata-rata ada yang diberikan selama 1-3 bulan sebelum pernikahan atau setelah berkas pendaftaran nikah telah lengkap dan diselesaikan kirakira seminggu sebelum acara pernikahan dilangsungkan. Dengan frekuensi pertemuan yang semakin sering dan lama diharapkan calon pengantin dapat mengambil manfaat dari proses konseling pranikah tersebut. Manfaat dari konseling pranikah diantaranya, calon pengantin mengerti tugas dan kewajiban dalam 
rumah tangga, mampu menjalani rumah tangga dengan baik, mempersiapkan diri secara lahir batin, manajemen keluarga, syarat dan pedoman pernikahan, serta hal penting yang dapat diambil dari proses ini adalah supaya dapat menekan angka perceraian dalam rumah tangga dengan memahami arti dari pernikahan tersebut.

Tabel 7. Pelaksanaan Konseling Pra Nikah Berdasarkan Metode Konseling

\begin{tabular}{lcccccccc}
\hline \multirow{2}{*}{$\begin{array}{l}\text { Metode } \\
\text { konseling }\end{array}$} & \multicolumn{4}{c}{ Pelaksanaan } & \multicolumn{2}{c}{ Total } \\
\cline { 2 - 9 } & \multicolumn{2}{c}{ Kurang } & \multicolumn{2}{c}{ Cukup } & \multicolumn{2}{c}{ Baik } & & \\
\cline { 2 - 9 } & $\mathrm{F}$ & $\%$ & $\mathrm{~F}$ & $\%$ & $\mathrm{~F}$ & $\%$ & $\mathrm{~F}$ & $\%$ \\
\hline Ceramah & 3 & 14,29 & 0 & 0 & 0 & 0 & 3 & 14,29 \\
\hline Diskusi & 1 & 4,76 & 16 & 76,19 & 0 & 0 & 17 & 80,95 \\
\hline $\begin{array}{l}\text { Ceramah dan } \\
\text { diskusi }\end{array}$ & 0 & 0 & 1 & 4,76 & 0 & 0 & 1 & 4,76 \\
\hline Total & 4 & 19,05 & 17 & 80,95 & 0 & 0 & 21 & 100 \\
\hline
\end{tabular}

Secara keseluruhan tidak ada pelaksanaan berkategori baik berdasarkan media yang digunakan. Metode diskusi yang digunakan dalam konseling pranikah dinilai efektif. Pada proses metode diskusi dalam menyampaikan konseling antara calon pengantin dan petugas konselor terjadi komunikasi yang efektif. Calon pengantin memiliki kesempatan untuk bertanya tentang hal-hal yang belum diketahui tentang materi yang disampaikan dan petugas dapat menjawab pertanyaan calon pengantin saat itu juga.

Tabel.8. Pelaksanaan konseling pra nikah berdasarkan media penyampaian

\begin{tabular}{|c|c|c|c|c|c|c|c|c|}
\hline \multirow{3}{*}{$\begin{array}{l}\text { Media } \\
\text { penyampaian }\end{array}$} & \multicolumn{6}{|c|}{ Pelaksanaan } & \multirow{2}{*}{\multicolumn{2}{|c|}{ Total }} \\
\hline & \multicolumn{2}{|c|}{ Kurang } & \multicolumn{2}{|c|}{ Cukup } & \multicolumn{2}{|c|}{ Baik } & & \\
\hline & $\mathrm{F}$ & $\%$ & $\mathrm{~F}$ & $\%$ & $\mathrm{~F}$ & $\%$ & $\mathrm{~F}$ & $\%$ \\
\hline Tanpa media & 1 & 4,76 & 3 & 14,29 & 0 & 0 & 4 & 19,05 \\
\hline Hanya & 3 & 14,29 & 13 & 61,90 & 0 & 0 & 16 & 76,19 \\
\hline
\end{tabular}

\begin{tabular}{lcccccccc}
\hline buku/leaflet & & & & & & & & \\
\hline Multimedia & 0 & 0 & 1 & 4,76 & 0 & 0 & 1 & 4,76 \\
\hline Total & 4 & 19,05 & 17 & 80,95 & 0 & 0 & 21 & 100 \\
\hline
\end{tabular}

Secara keseluruhan tidak ada pelaksanaan yangberkategori baik berdasarkan media penyampaiannya. Untuk media penyampaian dari masingmasing tempat pelayanan pernikahan memiliki kebijakan sendiri-sendiri untuk mengembangkan media yang akan digunakan oleh petugas konselor. Penggunaan media merupakan salah satu sarana penunjang dalam keberhasilan memberikan konseling kepada calon pengantin.

Tabel 9. Pelaksanaan konseling pra nikah berdasarkan materi yang disampaikan

\begin{tabular}{|c|c|c|c|c|c|c|c|c|}
\hline \multirow{3}{*}{$\begin{array}{l}\text { Materi yang } \\
\text { disampaikan }\end{array}$} & \multicolumn{6}{|c|}{ Pelaksanaan } & \multirow{2}{*}{\multicolumn{2}{|c|}{ Total }} \\
\hline & \multicolumn{2}{|c|}{ Kurang } & \multicolumn{2}{|c|}{ Cukup } & \multicolumn{2}{|c|}{ Baik } & & \\
\hline & $\mathrm{F}$ & $\%$ & $\mathrm{~F}$ & $\%$ & $\mathrm{~F}$ & $\%$ & $\mathrm{~F}$ & $\%$ \\
\hline Tidak diberikan & 0 & 0 & 0 & 0 & 0 & 0 & 0 & 0 \\
\hline $\begin{array}{l}\text { Diberikan tidak } \\
\text { lengkap }\end{array}$ & 4 & 19,05 & 8 & 38,10 & 0 & 0 & 12 & 57,15 \\
\hline Diberikan lengkap & 0 & 0 & 9 & 42,85 & 0 & 0 & 9 & 42,85 \\
\hline Total & 4 & 19,05 & 17 & 80,95 & 0 & 0 & 21 & 100 \\
\hline
\end{tabular}

Dari keseluruhan tempat pelayanan kesehatan pada dasarnya sudah memberikan materi konseling pranikah namun mayoritas materi yang disampaikan tidak lengkap. Materi yang disampaikan dalam konseling pranikah disetiap tempat pelaksana pernikahan memiliki perbedaan atau karakteristik masing-masing sesuai pengembangan dari tempat pelaksana. Materi yang disampaikan saat konseling pranikah diantaranya materi tentang 
kehidupan berumah tangga dari sudut pandang agama, sosial ekonomi keluarga, pengetahuan umum dan materi tentang kesehatan.

\section{OUTPUT KONSELING PRANIKAH DI LAYANAN PERNIKAHAN}

\section{Tabel 10. Kebutuhan kesehatan reproduksi dalam konseling pranikah}

\begin{tabular}{|c|c|c|c|c|c|c|c|c|}
\hline \multirow{3}{*}{$\begin{array}{l}\text { Kebutuhan } \\
\text { kesehatan } \\
\text { reproduksi }\end{array}$} & \multicolumn{6}{|c|}{ Pelaksanaan } & \multirow{2}{*}{\multicolumn{2}{|c|}{ Total }} \\
\hline & \multicolumn{2}{|c|}{ Kurang } & \multicolumn{2}{|c|}{ Cukup } & \multicolumn{2}{|c|}{ Baik } & & \\
\hline & F & $\%$ & $\mathrm{~F}$ & $\%$ & $\mathrm{~F}$ & $\%$ & $\mathrm{~F}$ & $\%$ \\
\hline Membutuhkan & 3 & 14,28 & 16 & 76,2 & 0 & 0 & 19 & 90,48 \\
\hline $\begin{array}{l}\text { Tidak } \\
\text { membutuhkan }\end{array}$ & 1 & 4,76 & 1 & 4,76 & 0 & 0 & 2 & 9,52 \\
\hline Total & 4 & 19,04 & 17 & $\begin{array}{c}80,9 \\
6 \\
\end{array}$ & 0 & 0 & 21 & 100 \\
\hline
\end{tabular}

Mayoritas kebutuhan akan konseling pranikah tentang kesehatan reproduksi didasari atas kesadaran bahwa hal ini sangat dibutuhkan melihat tujuan dari pernikahan salah satunya adalah membangun keluarga yang sehat. Kebahagiaan keluarga yang harmonis juga di dukung oleh kesehatan reproduksi yang baik dari masing-masing pasangan dan masih banyak masyarakat diluar yang kurang memahami tentang kesehatan reproduksi.

Kebutuhan akan pemeriksaan kesehatan sebelum menikah berperan penting dan dapat dianggap sebagai langkah awal dalam pembentukan keluarga sakinah, demi tercapainya kesehatan yang terjamin dalam sebuah keluarga karena kesehatan merupakan salah satu indikator keluarga sakinah. Oleh karena itu dengan pemeriksaan akan dapat diketahui penyakit-penyakit yang dapat mengancam kelangsungan dan ketenangan sebuah keluarga. Sebagian responden mengatakan sangat setuju dilakukan pemeriksaan kesehatan pranikah, walaupun saat ini hanya sebatas pemberian imunisasi TT (Tetanus Toxoid) yang dilakukan tempat pelayanan kesehatan. Hal ini sesuai dengan Keputusan Depkes No.02 Tahun 1989 tentang suntik TT (Tetanus Toxoid) bagi calon pengantin diterapkan melalui KUA menjadi syarat wajib administratif. Pada kenyataan dilapangan yang mendapatkan imunisasi TT (Tetanus Toxoid) hanya bagi calon pengantin yang mendaftarkan pernikahannya di KUA, sedangkan bagi calon pengantin yang mendaftarkan pernikahannya selain di KUA tidak diwajibkan untuk mendapatkan imunisasi TT (Tetanus Toxoid).

\section{KESIMPULAN}

Pengetahuan calon pengantin tentang kesehatan reproduksi secara keseluruhan berkategori baik sebanyak 35 orang $(68,6 \%)$ dan pengetahuan yang berkategori cukup sebanyak 16 orang $(31,4 \%)$. Namun, pengetahuan yang baik tidak didukung dengan pemahaman yang baik tentang kesehatan reproduksi. Pelaksanaan 
konseling pranikah di Kota Tarakan secara umum dalam kategori cukup sebanyak 17 tempat pelaksana $(80,95 \%)$ dan kategori kurang sebanyak 4 tempat pelaksana $(19,05 \%)$ yang dinilai mencakup kebijakan, SDM (Sumber Daya Manusia), sarana/prasarana, pedoman; waktu, lama, metode, media dan materi.

Konseling pranikah di Kota Tarakan sebanyak 90,48\% membutuhkan untuk dilakukan konseling pranikah tentang kesehatan reproduksi.

\section{Referensi}

Alimul, A. (2007). Metode Penelitian Kebidanan dan Teknik Analisis Data. Surabaya.: Salemba Medika.

Aminuddin, F. (2008). Bimbingan Seksualitas Pra Nikah

(Skripsi).http://digilib.uin-

suka.ac.id/1765/1/BAB\%2520I,\%25

20BAB\%2520V,\%2520DAFTAR\%2 520PUSTAKA.pdf

Arikunto, S. (2010). Prosedur Penelitian

Suatu Pendekatan Praktik. Jakarta: Rineka Cipta,

Depkes RI. (2007). Modul Pelatihan

Pelayanan Kesehatan Peduli

Remaja,

Depkes RI. (2008). Program Kesehatan

Reproduksi dan Pelayanan Integratif

di Tingkat Pelayanan Dasar.
Direktorat Jenderal Bina Kesehatan Masyarakat. Jakarta.

GKI Kwitang. Alasan Mengapa Pasangan Buuh Konseling Pranikah. 2014. http://www.gkikwitang.or.id/artikel/s ingle/ini-alasan-kenapa-pasanganbutuh-konseling-pranikah.html

Ketut Sukardi, D. (2002). Pengantar Pelaksanaan Program Bimbingan dan Konseling di Sekolah. Tabanan. Rineka Cipta,

Kusmiran, E. (2011). Kesehatan Reproduksi Remaja dan Wanita. Bandung: .Salemba Medika,

Liliweri, A. (2006). Dasar - dasar Komunikasi Kesehatan. Yogyakarta: Pustaka Pelajar,

Manuhuruk, R V. (2012). Persepsi Tentang Konseling Pranikah pada Mahasiswa Tingkat Akhir (Skripsi). http//:lib.ui.ac.id/file?file=digital/203 01746-S42032

Valentina\%2520ROSA\%2520Manih uruk.pdf.

Notoatmodjo. S. (2005). Metodologi Penelitian Kesehatan. Bandung: Rineka Cipta,

Pedoman Pelaksanaan Kegiatan KIE Kespro. http://.gizikia.depkes.go.id diakses tanggal 23 Agustus 2014

Program Kesehatan Reproduksi Pelayanan Integratif Di Pelayanan Dasar. 
www.gizikia.depkes.go.id. Diakses tanggal 23 Agustus 2014.

Saifuddin, B. (2003). Buku Panduan

Praktis Pelayanan Kontrasepsi.

Jakarta : Yayasan Bina Pustaka

Sarwono Prawirohardjo,

Saryono dan Mekar Dwi. (2013).

Metodologi Penelitian Kualitatif dn

Kuantitatif dalam Bidang Kesehatan.

Yogyakarta: Nuha Medika.

Sugiyono. (2013). Metode Penelitian

Kuantitatif, Kualitatif dan $R \& D$.

Bandung : Alfabeta,

Sunyoto. D. (2011). Analisis Penelitian

Kesehatan, Nuha Medika,

Yogyakarta.

Suyanto. (2011). Metodologi dan Aplikasi

Penelitian Keperawatan, Nuha

Medika, Yogyakarta

Willis, S. (2004). Konseling Individual

Teori dan Praktek, Alfabeta,

Bandung.

Widyastuti, Y, dkk. (2011). Kesehatan

Reproduksi, Fitramaya. Yogyakarta.

Zulaikha, O. (2013). Bimbingan Konseling

Pranikah bagi Calon Pengantin di BP4 KUA Kecamatan Mranggen

(Studi Analisis Bimbingan Konseling

Perkawinan).

http://eprints.walisongo.ac.id/id/eprin t/1893. 